doso en la 1

ar ejemplos a

is funcionalidac uso, dependiende encarnan los conceptos detr por e $\Lambda$ influ
$\mathrm{Pe}$ infin:

Las formas $d r$ oceso de sig ialidad .

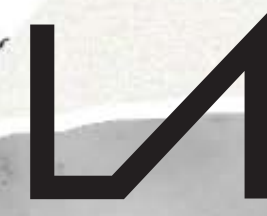

R E V I S A
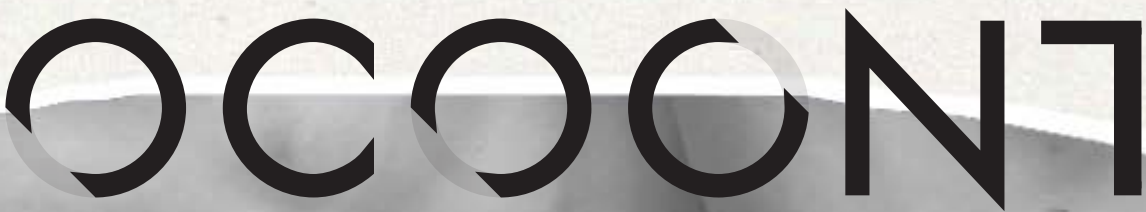

D $E$

No $6 \cdot 2019 \cdot$ ISSN 2386-8449

"El producto del diseñador es un proyecto, el estado previo de un objeto", Entrevista con Norberto Chaves, por Fernando Infante

El papel de la investigación y la teoría en diseño. Una conversación abierta, por Fernando Infante y María Jesús Godoy

UT PICTURA POESIS

Abandonar la escritura. Poesía experimental y manifiesta, Ignacio Gómez de Liaño

PANORAMA: FILOSOFÍA DEL DISEÑO Sección coordinada por Fernando Infante y María Jesús Godoy

Pensar el diseño, Fernando Infante y María Jesús Godoy (Coordinadores)

TEXTOS INVITADOS

Estatus y estado del điseño más allá del objeto, Pedro Medina Reinón

Mar de Nubes, Cuerpo de Cristal, Dionisio González

ARTÍCULOS

Understanding Design Aesthetics beyond Functional Beauty accounts, Lucía Jiménez Sánchez

Estética y diseño industrial: debates y controversias, Joan M. Marín

Del ornamento al delito. El diseño y la sociedad en Charles Baudelaire y Adolf Loos, Jorge López Lloret

When is Architecture not Design? Saul Fisher

Diseño y habitabilidad: una aproximación basada en los lenguajes de patrones, Antonio Hidalgo Pérez

Marcel Breuer: un diseñador global. Experiencias en el ámbito de la vivienda prefabricada, Salvador J. Sanchis, Ignacio Peris y Pedro Ponce Diseño y artes escénicas: el papel de Oskar Schlemmer en Das Triadische Ballett y la actualidad de la Bauhaus, Milagros García Vázquez Lo performativo en prácticas de arte y diseño actuales vinculadas a procesos de innovación social. El caso de La Venezia che non si vede y de La borda, Tània Costa Gomez

Articulaciones de la estética y el diseño. El caso de la evaluación a partir de la investigación dirigida en la carrera de diseño escénico de la Universidad de las Artes de Cuba, Mara Rodríguez Venegas y Xiomara Romero Rojas

SUPLEMENTO

El diseño, la ciudad y un lápiz de labios, Mercedes Espiau, Mar García Ranedo y Alejandro Rojas mas. 


\section{UつCつCNTE}

No $6 \cdot 2019 \cdot \operatorname{ISSN} 2386-8449 \cdot$ DOI 10.7203/LAOCOONTE.5.15381

https://ojs.uv.es/index.php/LAOCOONTE/index

COORDINACIÓN EDITORIAL

Anacleto Ferrer (Universitat de València)

Francesc Jesús Hernàndez i Dobon (Universitat de València)

Fernando Infante del Rosal (Universidad de Sevilla)

SECRETARÍA DE REDACCIÓN

Lurdes Valls Crespo (Universitat de València)

Vanessa Vidal Mayor (Universitat de València)

COMITÉ DE REDACCIÓN

Tamara Djermanović (Universitat Pompeu Fabra), Rosa Fernández Gómez (Universidad de Málaga), Anacleto Ferrer (Universitat de València), Ilia Galán (Universidad Carlos III), Ana María García Varas (Universidad de Zaragoza), María Jesús Godoy (Universidad de Sevilla), Fernando Infante del Rosal (Universidad de Sevilla), Miguel Ángel Rivero (Universidad de Sevilla), Miguel Salmerón (Universidad Autónoma de Madrid), Gerard Vilar (Universitat Autònoma de Barcelona).

COMITÉ CIENTÍFICO INTERNACIONAL

Rafael Argullol* (Universitat Pompeu Fabra), Luis Camnitzer (State University of New York), José Bragança de Miranda (Universidade Nova de Lisboa), Bruno Corà (Università di Cassino), Román de la Calle* (Universitat de València), Eberhard Geisler (Johannes Gutenberg-Universität Mainz), José Jiménez* (Universidad Autónoma de Madrid), Jacinto Lageira (Université Paris 1 Panthéon-Sorbonne), Bernard Marcadé (École Nationale Supérieure d'Arts de Paris-Cergy), Elena Oliveras (Universidad de Buenos Aires y Universidad del Salvador), Pablo Oyarzun (Universidad de Chile), Francisca Pérez Carreño* (Universidad de Murcia), Bernardo Pinto de Almeida (Faculdade de Belas Artes da Universidade do Porto), Luigi Russo (Università di Palermo), Georges Sebbag (Doctor en Filosofía e historiador del surrealismo), Zoltán Somhegyi (University of Sharjah, United Arab Emirates), Robert Wilkinson (Open University-Scotland), Martín Zubiria (Universidad Nacional de Cuyo). *Miembros de la Sociedad Española de Estética y Teoría de las Artes, SEyTA

\begin{tabular}{lll}
\hline DIRECCIÓN DE ARTE & REVISIÓN DE TEXTOS & TRANSCRIPCIÓN DE TEXTOS \\
El golpe. Cultura del entorno & Antonio Cuesta & Álvaro G. Serna
\end{tabular}

(cc) BY Excepto que se establezca de otra forma, el contenido de esta revista cuenta con una licencia Creative Commons Atribución 3.0 España, que puede consultarse en http://creativecommons.org/licenses/by/3.0/es/deed.es

EDITA

\section{SEyTA.}

CON LA COLABORACIÓN DE

\begin{tabular}{|c|c|c|c|}
\hline $\begin{array}{l}\text { VNIVERSITAT } \\
\text { ID VALENCIA } \\
\text { Institut a Creativitat } \\
\text { i|nnovacions Educatives }\end{array}$ & $\begin{array}{l}\text { VNIVERSITAT } \\
\text { IE ÖVALENCIA Departament de Filosofia }\end{array}$ & 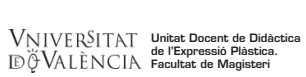 & \\
\hline $\begin{array}{l}\text { DEPARTAMENTO DE ESTÉTICA } \\
\text { E HISTORIA DE LA FILOSOFIA }\end{array}$ & $\frac{\text { UAW }}{\frac{\text { UNIVERSIDAD AUTONOMA }}{\text { DE MADRID }}}$ & $\begin{array}{l}\text { AB } \\
\text { Universitat Autònoma } \\
\text { de Barcelona }\end{array}$ & 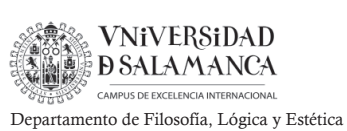 \\
\hline
\end{tabular}

LAOCOONTE aparece en los catálogos: 


\section{LつCつCN7E}

"Cuanto más penetramos en una obra de arte más pensamientos suscita ella en nosotros, y cuantos más pensamientos suscite tanto más debemos creer que estamos penetrando en ella".

G. E. Lessing, Laocoonte o los límites entre la pintura y la poesía, 1766.

Vo hay cól.

létodo, de pen.

:ión en general. Ith

zar la forma para el $\mathrm{n}$.

eptual por las orígenes

la, el objeto, la exposición

storia, porque existe en el $\mathrm{m}$

das sus raíces. Desde alli cc _. panoram

n conceptual y donde el émencia del con 'iseñado, como es el a al objeto y el di $\begin{array}{ll}\text { igen } \mathrm{de}^{\text {to }} \text { la inmer } & \text { tolvidada, o comc } \\ \text { trozo de madera ar }\end{array}$ a manera dorm comunicar ene nundo. Seguin? sngo en manos te el método $C$ les. A partir c teria prima $\mathrm{p}_{\mathbf{c}}$

'xto se puede:

¿ño, en proyea

amientos de $\mathrm{u}$

a conscie-

.)

en la publicación jue "plos de la impor te las nalidades porqu ura un ${ }^{2}$ diendo de qui zenerar $\mathrm{u}$ ción de nr? lne

in-

n-

is.

le http:,

le crear visualidades. A partir de.

ellas la propia materia prima para un en que desde un texto se puede generar $u_{11}$ i

Pensar en diseño, en proyección de nue

posibles comportamientos de una colecti

presente como una consciencia del hecho que estamos elaborando, significac

nuestro entorno (..)

Cardoso, R. C. Rafael. (2014). Design para um mundo complexo. Sãc asil: Cosac Naify. 


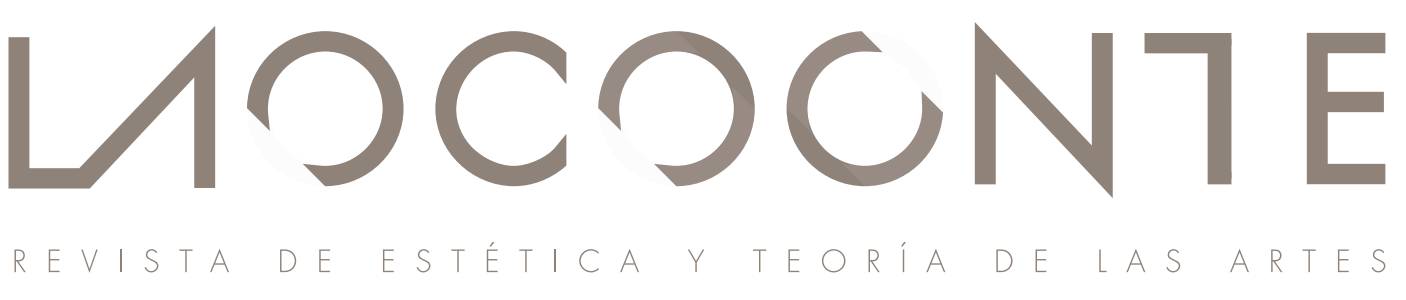

$\mathrm{N}^{\circ} 6 \cdot 2019$

PRESENTACIÓN

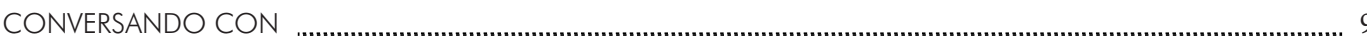

"El producto del diseñador es un proyecto, el estado previo de un objeto", Entrevista con Norberto Chaves,

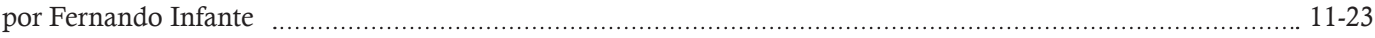

El papel de la investigación y la teoría en diseño. Una conversación abierta, por Fernando Infante

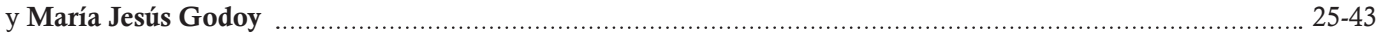

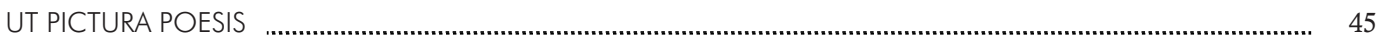

Abandonar la escritura. Poesía experimental y manifiesta, Ignacio Gómez de Liaño ................................................ 47-95

Imágenes de Laocoonte n. 6, de Isadora Gonzaga ................................................................................................... 96-97

PANORAMA

FILOSOFÍA DEL DISEÑO

Pensar el diseño, Fernando Infante y María Jesús Godoy (Coordinadores) .............................................. 101-105

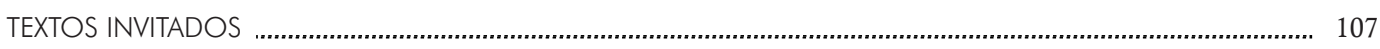

Estatus y estado del diseño más allá del objeto, Pedro Medina Reinón . ................................................... 109-125

Mar de Nubes. Cuerpo de Cristal, Dionisio González .............................................................................. 127-133

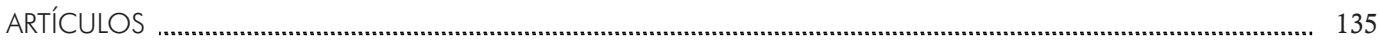

Understanding Design Aesthetics beyond Functional Beauty accounts, Lucía Jiménez Sánchez ................. 137-149

Estética y diseño industrial: debates y controversias, Joan M. Marín _...................................................... 150-164

Del ornamento al delito. El diseño y la sociedad en Charles Baudelaire y Adolf Loos, Jorge López Lloret ... $165-182$

When is Architecture not Design? Saul Fisher ……............................................................................. 183-198

Diseño y habitabilidad: una aproximación basada en los lenguajes de patrones, Antonio Hidalgo Pérez ...... 199-215

Marcel Breuer: un diseñador global. Experiencias en el ámbito de la vivienda prefabricada,

Salvador José Sanchis, Ignacio Peris y Pedro Ponce

Diseño y artes escénicas: el papel de Oskar Schlemmer en Das Triadische Ballett y la actualidad de la Bauhaus, Milagros García Vázquez

Lo performativo en prácticas de arte y diseño actuales vinculadas a procesos de innovación social.

El caso de La Venezia che non si vede y de La borda, Tània Costa Gomez

Articulaciones de la estética y el diseño. El caso de la evaluación a partir de la investigación dirigida en la carrera de diseño escénico de la Universidad de las Artes de Cuba, Mara Rodríguez Venegas

y Xiomara Romero Rojas

SUPLEMENTO 
Walter Gropius. La vida del fundador de la Bauhaus, Jorge Martínez Alcaide

¿Qué significa pensar la política desde la estética? Àger Pérez Casanovas

Ideologías estéticas en los orígenes de la pintura moderna, José Luis Plaza Chillón 300-303

Sobre a estética, Luis Carlos Pereira

Músicas populares. Sociedad y territorio: Sinergias entre investigación y docencia, Mar Aleixandre Badenes.

307-309

La necesidad de la mirada antropológica sobre la literatura, Pablo de Benito David

A propósito de Chandler, o la novela policíaca como tratado filosófico, Juan Evaristo Valls Boix

Videre aude!, Anacleto Ferrer

La inaplazable memoria del dolor y el sufrimiento, Antonio Notario Ruiz

La alargada sombra de la pintura, Raquel Baixauli

Sondear la maravilla, Juan Evaristo Valls Boix

... Y lo sabes, Marc Hernández Montoro

Arqueologías de la modernidad en las artes. Ensayo estético, Carlota Fernández-Jáuregui Rojas

Estética de la Instalación, Luis Cemillán Casis

La Herencia de otra época, María Jesús Godoy Domínguez

Del Theatrum Mundi al Gran Vidrio, Miguel Salmerón Infante

Imágenes de Isadora Gonzaga.

Fotografía de portada de Tamara Djermanovic intervenida por Isadora Gonzaga.

Los coordinadores de la sección Panorama: Filosofia del diseño agradecen

a Antonio Molina Flores su colaboración. 
ner.

llobj vidada, o de ma la publica. los de la im nalidades po ndientn $\mathrm{A}$ -
, la

que e.

usdño, si nn

ज. " da yara el mu tual y d

or enc or las orígenes un tmo, fía del diseño,

rpintero que'curra la forma de

eña Desige para un mundo complexo, de los bienes producidos por el hombre :tores subjetivos también influyen en su

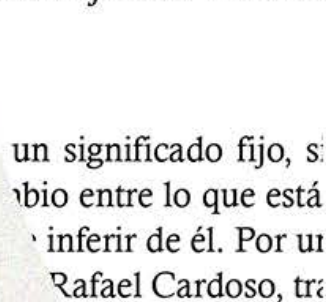

Rafael Cardoso, tri

No hay cómo no e método, de pensa 1, donde la reación en geperal. salizar la forma pa. rue amb ${ }_{\text {Snceptual por }}{ }^{1}$

$$
\text { -rola ol } n^{\prime}
$$

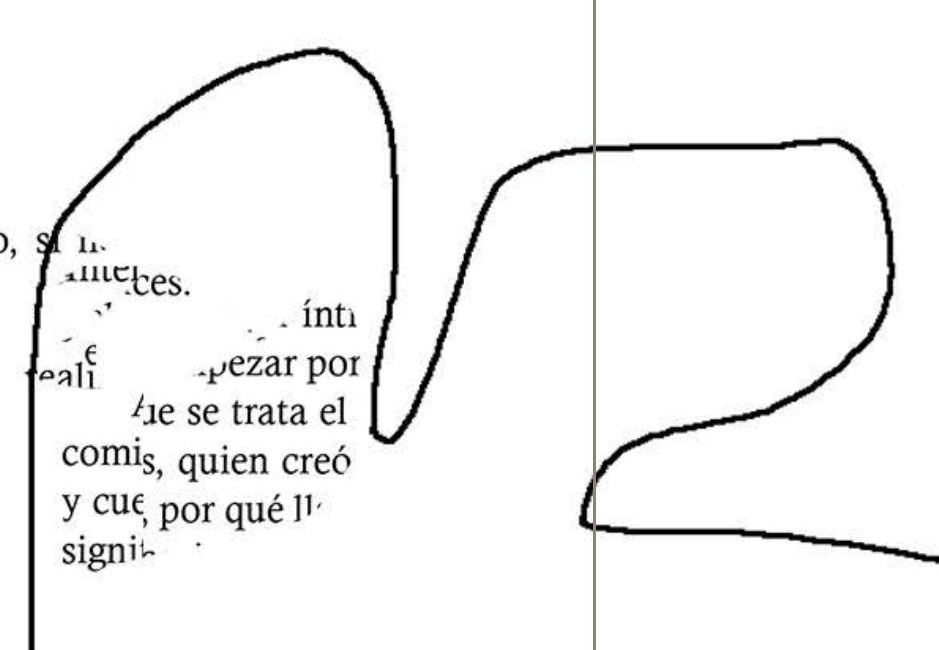

LOCOCNTE

PANORAMA: FILOSOFÍA DEL DISEÑO

Fernando Infante del Rosal y María Jesús Godoy Domínguez

(Coordinadores) 
No hay cómo no hablar de una filosofía del diseño, si no de izar la forma para el mundo sensible. Tción de formas y de la

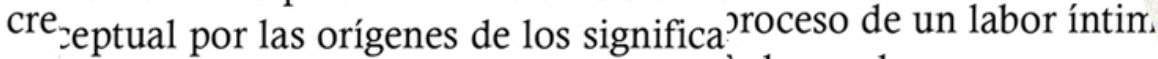

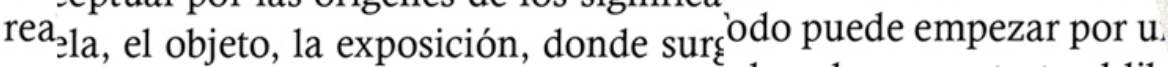

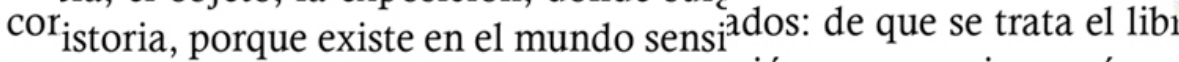
noładas sus raíces. Desde allí cojo el hilo gió, que es, quien creó y p su len conceptual y donde el está ubicado.ible o aún, por qué llama as

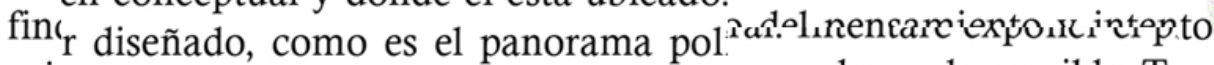
ori $_{\text {evolando la inmanencia del concepto. }}$ para el mundo sensible. Tc ce a s a forma al objeto y el diseñad ${ }^{\text {as }}$ orígenes de los significa)olo sob lengua olvidada, o como un cr la exposición, donde surg̨ido - nrocesr a un trozn de madera amnrfo le existe en el mundo sensin trai lengua olvidada,adas sus raíces. Desde allí cojo el hilona de ablo de procesc a un trozo de men conceptual y donde el está ubicado. perspectiva de lidoso en la publr diseñado, como es el panorama polndo ho, un camino diar ejemplos de levolando la inmanencia del concepto.: por una investigacióus funcionalidadı a forma al objeto y el diseñadı infl ro, el cuento, luso, dependiendı lengua olvidada, o como un $\mathrm{C} i^{\prime}$

qué, cuál e s nrecese a un trozo de madera amorfo

ata el 1

،en creó y pu.

or qué llama así, d

miento y intento a lles
- puede inferir de él. Por un in -reación ". (Rafael Cardoso, trad. 26 el ambiente que cerca el ol, especie de un danza en que ambos eleme iles son los símbolos que estso.

lmente, el contenido contextrño y hacer diseño, es antes de todo cue rna el papel de un tra o que toma la forma $\mathrm{d}^{\text {g }}$ gradual, donde la idea $\mathrm{do}_{\text {, las ideas, los relacioname }}$ danza en que ambos ropio proceso y también de r

'esign para un mundo liseñar, me planteé la cuesti' s bienes producidos por seño, es antes de tod prima eso me dá? Ejemp' es subjetivos también inf ble. Diseñar puede se ese texto, construyo el d

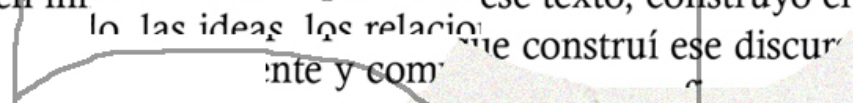

1 un significado fijo, sino que expresajue ${ }^{\dagger}$ mbio entre lo que está incrustado en Sre ¿de inferir de él. Por un lado, las form ". (Rafael Cardoso, trad. 2014)

rradual, donde la i’ 
- ormas y de rapo.

eso de un labor íntimo, un udo puede empezar por una inves 'dos: de que se trata el libro, el cu jió, que es, quien creó y por qué, ble o aún, por qué llama así, donı del pensamiento y intento a lle: Cual es el ambiente que cerca e ico. cuáles son los símholos aı

de una filosofía del diseño, si r e construcción de formas y de exponer el proceso de un labor í o sensible. Todo puede empezar los significados: de que se trata h, donde surgió, que es, quien creó y po mundo sensible o aún, por qué llama as cojo el hilo del pensamiento y intentc está ubicado. Cual es el ambiente que $\mathrm{g}$ anorama político, cuáles son los símb el concepto. Gradualmente, el conten y el diseñador encarna el papel de ur como un carpintero que toma la forr
LAU1 L11 glilla1. 111 n un sigizar la forma para e] ede inferifeptual por las orígt “. (Rafabla, el objeto, la exp istoria, porque exist y gradua adas sus raíces. De: en conceptual y do sible. $D$ : $r$ diseñado, como do, las icevolando la inman propio pri diseñar, a forma al prima e lengua olvi ese textos nrncesr a un trnzo ue construí ese discurso, he hecho de ara un reconfiguración de significado en para ilustrar... (en construccion) antiguas formas, es lanzar al mundo 1. La responsabilidad aquí se hace tamos elaborando, significados para

am mundo complexo. São Paulo,

1 agosto). Significado. Recuperado 1 br/significado/

\section{ИつCつCN7E}

PANORAMA: FILOSOFÍA DEL DISEÑO ARTÍCULOS 
- ormas y de rapon

aso de un labor íntimo, un udo puede empezar por una inves 'dos: de que se trata el libro, el cu rió, que es, quien creó y por qué, ble o aún, por qué llama así, donı del pensamiento $\mathrm{y}$ intento a lle Cual es el ambiente que cerca e ticn. cuáles son los símbolos a

de una filosofía del diseño, si r e construcción de formas y d $\epsilon$ exponer el proceso de un labor í o sensible. Todo puede empezar. los significados: de que se trata 1, donde surgió, que es, quien creó y po mundo sensible o aún, por qué llama as cojo el hilo del pensamiento y intento está ubicado. Cual es el ambiente que $q$ anorama político, cuáles son los símb lel concepto. Gradualmente, el conten y el diseñador encarna el papel de u somo un carpintero que toma la forr

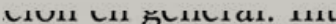
un signizar la forma para e] ambio eni ede inferieptual por las oríge n ". (Rafaəla, el objeto, la exp y gradua istoria, porque exist n danza adas sus raíces. De: en conceptual y do] sible. Dis $r$ diseñado, como do, las icevolando la inmanı ropio pri diseñar, $r$ ¥ forma al prima e lengua olvi

ese textos nrncesr a un trnzo ue construí ese discurso, he hecho de ara un reconfiguración de significado en para ilustrar... (en construccion) antiguas formas, es lanzar al mundo 1. La responsabilidad aquí se hace stamos elaborando, significados para

um mundo complexo. São Paulo,

1 agosto). Significado. Recuperado 1 $\mathrm{br} /$ significado/ 


\title{
Understanding Design Aesthetics beyond Functional Beauty Accounts
}

\section{Comprender la estética del diseño más allá de los enfoques de belleza funcional}

\author{
Lucía Jiménez Sánchez
}

\begin{abstract}
Design is presented as an apt object of aesthetic appreciation. The nature of its aesthetic dimension will be developed in terms of the relationship between form and function. Specially, by looking at the role that knowledge about function plays in our design aesthetic judgements. Then, I will present the dominant view about the aesthetic value of design coming from functional beauty accounts. Finally, in the last section, I will focus upon some problems derived from the aforementioned integral model form-function in design aesthetics. By means of practical cases, I will point to the narrowness of functional beauty accounts and its inability to include a broader range of actual design objects and their relevant design aesthetic properties.
\end{abstract}

Keywords: design aesthetic value, form-function relationship, proper function, functional or dependent beauty, design beauty.

\begin{abstract}
Resumen
El diseño se presenta como un objeto competente para la apreciación estética. La naturaleza de su dimensión estética será desarrollada en términos de la relación entre la forma y la función, prestando especial atención al rol que el conocimiento sobre la función juega en nuestros juicios estéticos de diseño. De modo que expondré la visión dominante sobre el valor estético del diseño proveniente de los enfoques de belleza funcional. En última instancia, me centraré en algunos problemas derivados del citado modelo integral forma-función en la estética del diseño. Mediante el uso de casos prácticos, apuntaré hacia la limitación de los enfoques de belleza funcional en vista a su incapacidad para acoger un rango mayor de objetos de diseño actuales y de sus propiedades estéticas más relevantes.
\end{abstract}

Palabras clave: valor estético del diseño, relación forma-función, función apropiada, belleza funcional o dependiente, belleza de diseño.

\section{Introduction}

As an object of philosophical study, design presents a seemingly puzzling nature. We are all surrounded by design objects: chairs, coffee-pots, Zara heels, cars, Wikipedia, satellites. However, despite its mundane condition, we rarely speak about them as being valuable aesthetic objects. As noticeable beautiful treasures. This extraordinary omission is paradoxical regarding design ordinariness. Fortunately, some philosophers

* Universidad de Murcia, España.jimenezsanchez.lucia@gmail.com Artículo recibido: 1 de junio de 2019; aceptado: 15 de octubre de 2019 
have recently echoed this fact by pushing the boundaries of philosophical aesthetics and claiming for design's importance (Folkman (2013), Forsey (2013), Parsons (2016)). But, why has design gone so theoretically unnoticed when it was supposedly before our eyes? As Jane Forsey points out, although this omnipresence of design does not justify a lack of aesthetic interest, it seems that this same mundane condition explains why design has been so neglected by traditional aesthetics. Thus, there is no reason to disregard that we do actually have valuable aesthetic experiences with design objects. In fact, there are several current aesthetic accounts that are primarily focused on what is peculiar about the aesthetic appreciation of broadly non-artistic objects -design objects included. Hence, following these approaches, I will defend the view that design objects are proper objects of aesthetic appreciation. That means design has a particular kind of aesthetic value as design.

\section{The Object of Design}

Design objects are intentional artefacts, products of human intentions that have been designed with the aim of fulfilling some purpose or function. ${ }^{1}$ They are mainly quotidian objects that give shape to our material cultures and whose production is generally linked to the satisfaction of a particular (set of) function(s). A good example could be Little Sun Diamond, a solar lamp created by the artist Olafur Eliasson and the engineer Frederik Ottesen. It is the third member of the Little Sun Family: a basic solar lamp especially designed to foster sustainable and clean access to electric light in those parts of the world in which this is still a privilege. This design responds to Olafur's commitment with the idea of making something that is "so shared" -as the sunlight is - a thing that everybody can benefit from.

So, they came up with a portable solar lamp able to be placed in almost any surface. Its easiness and simplicity of use derives from its double-sided division. From one side, there is a solar panel that can be effortlessly oriented to the source of the sun. On the other, there is a bulb integrated within the design of a sunflower or a diamond (it depends on the model). Thus, the idea about how valuable is the sunlight cleverly instantiated in the appearance of the lamp as a diamond. As remarked by Riis Ebessen regarding Olafur's statement: "Little Sun is a work of art that works in life". It puts the power of sun in the palm of your hand. ${ }^{2}$ This really makes Little Sun Family stand apart from other conventional or functional solar lamps. ${ }^{3}$

Design objects are, thus, quotidian and functional objects that can provide us with familiar aesthetic experiences in our daily lives. Objects belonging to the categories of product design, interior design, graphic design, fashion design, web design, will be the objects we will be focusing upon. I mean, designs that designers bring into a material form. ${ }^{4}$ Nevertheless, design objects do not have to be quotidian to be design.

1 For a strong essentialist approach to function see Parsons, G. 2016. The Philosophy of Design. Cambridge: Polity Press.

2 About communicative complexities both in the material properties of its design and its discursive mediations, see Riis Ebbesen, T. 2017. "Little Sun: An Indicative Framework for the Analysis of Art and Design Objects". Design Issues, vol. 33, num. 1: 48-60.

3 What I further underline with this example is that objects with practical functions are good candidates for aesthetic appreciation when they are not unfairly conceived as mere everyday objects that "say nothing".

4 Although there are other design practices mostly from Design Thinking that focus on developing inmaterial designs -such as interactive design, service design or system design- here, I will engage with what I consider to be the 
There are lots of design objects that are not part of our daily lives, but that are still designed, such as particles accelerators or conceptual design cases. The key point for our approach is that the object of design needs to have a functional dimension as well as a material form. This is important because what is under dispute is how this material form and function interrelate in order to constitute the aesthetic dimension of design. Then, in what way a design object can be said to be beautiful? What is to aesthetically appreciate a design object?

\section{The Aesthetic Dimension of Design: A Form-Function Relationship}

We can distinguish at least two main approaches about the aesthetic value of design: Aestheticism and Functional Beauty Accounts. The first one is a traditional formalist account that can be called Aestheticism in design. This view focuses on the appreciation of the design object's form as treated in isolation from its function. The central claim of this approach is that form is understood as independent from function because it is considered as a matter of luck or of the designer's random choice. ${ }^{5}$ Following this view, the aesthetic value of design objects is bound to the formal properties of the object considered independently from any functional consideration. Therefore, this view promotes the idea that the aesthetic appreciation of design is only concerned with the external properties of objects understood as ornament or decoration. Further, another idea that can be derived from this aestheticist approach is that it turns the practice of design into a matter of appearances and, consequently, it makes design an added value of the object; that is, something that can be seen as superfluous or inessential for the object's true identity.

The Aestheticist approach also supports its scepticism concerning the pertinence of the relationship between form and function for design appreciation in the alleged indeterminacy of function. Thus, their neglect of function as relevant to design aesthetic judgements is based upon the controversy of the notion of function in itself: it seems problematic to clarify what exactly is that that the function of an object refers to. As some philosophers like Roger Scruton (1980) have suggested, function remains an "obscure notion" for objects that present us with practical aims. Similarly, according to David Pye (1978), function is a kind of "fantasy" -inasmuch as design objects cannot be ultimately determined by their successfulness about their deliberate o idealistic functions. These objections to the notion of function of the design object are often endorsed by those who defend design aestheticism.

Nevertheless, the problem of ignoring function is that design as a distinctive object of appreciation seems to "fade away" and not to be properly understood qua design. In fact, as Forsey notices, if form is understood as independent from other values -like function- there is no specific aesthetic value we can claim for design: not any special design beauty. This can be translated into the fact that we can find the same aesthetic value on a flower, a sonnet or a coffee-pot (as Stecker's maintains). Then, a problem for Aestheticism is that, if the aesthetic value of design objects is separable from its purpose, there is no way to characterize the aesthetic appreciation of design as

basic design case. That is, the one resulted from the practice of design as oriented to the production of an object to be appreciated as design.

5 See Pye, D. 1978. The Nature and Aesthetics of Design. New York: Van Nostrand Reinhold. 
involving a particular kind of beauty. ${ }^{6}$ Following this critical remark about Aestheticism, I will argue that design objects have a distinct kind of aesthetic value that is somewhat related to function, but that is not exclusively limited or determined by it.

Still, when we speak about function in the context of design objects' appreciation, which function are we talking about? Normally, we are referring to the proper or purposive function of the object. That is, the function that the object $\mathrm{O}$ must meet in order to belong to a particular kind, C. $^{7}$ For example, the proper function of a lamp is to shed light. That does not mean that we cannot ascribe other functions to the lamp -as when we use it as a coat hanger-but, in that case, these functions are called accidental functions. Thus, the main question is in which sense is our consideration of the design object's (practical) function relevant for its aesthetic dimension?

Looking now to the second predominant approach, the Functionalist Account, it seems unquestionable that function plays a much more relevant role in the aesthetic appreciation of design objects. For the Functionalist, the considerations about the function of a design object can shed some light to our aesthetic appreciation of design objects. According to this view, design beauty especially arises from a binomial relationship between form and function as a distinct kind of Functional Beauty. Functional Beauty approaches try to account for the knowledge that the purported function satisfied by design objects plays in our aesthetic appreciation of them. They notice that: "even if everyday objects in themselves are not, as are works of art, highly charged with meaning, a cognitively rich theory of our everyday aesthetic encounters can help to explain how it is that such experiences are nonetheless highly meaningful". 8 For that reason, they argue that knowledge about an object's function can enrich our aesthetic judgements and make us able to grasp aesthetic properties that design objects possess as design. One further purpose of this view is to offer a substantive judgement of the aesthetic achievement. That is, an aesthetic judgement based upon our knowledge concerning the functional success of the object. Aesthetically appreciating the object under the thought of the function it is meant to perform enriches in some way the aesthetic judgement and makes it less uncertain. Moreover, this seems to be coherent with design theoretical needs. Thus, in order to correctly appreciate a design object, we need to consider the relationship between its form and its intended function. Aesthetic value (design beauty) will emerge once we grasp a particular fitting relationship between these two elements that constitute the aesthetic appreciation of design.

Following this approach, and after having explained how our design aesthetic judgements can be partly determined by the particular relationship between form and function, we can conclude that function can be relevant to our design aesthetic judgement insofar as it makes us recognize some significant aesthetic properties of design objects. This means to acknowledge that intended function is part of the content handled by design aesthetic judgements. In what follows, we will focus upon the especial aesthetic attention that functional accounts grant to (practical) function and upon their account of beauty in design.

6 See Forsey, J. 2013. The Aesthetics of Design. Oxford: Oxford University Press.

7 "The most basic idea behind the notion of a proper function is the idea that it is the function that belongs to the object itself". Cited in Carlson, A. and Parsons, G. 2008. Functional Beauty. New York: Oxford University Press. pp. 66 . 


\section{The Functional Approach: Functional Beauty Accounts}

As I said before, Functional Beauty accounts hold that appreciating certain aesthetic properties requires appreciating the design object as designed for a particular function. Parsons \& Carlson (2008) and Stephen Davies (2010) agree that it is "a kind of beauty that objects exhibit by virtue of the kind of function they have and whose appreciation requires knowledge about its function". ${ }^{9}$ For P\&C, our aesthetic judgements must be based on a perceptual experience of the object's appearance as seeing under the corresponding 'functional category' we apply to the object. In these sense, they adapt Kendall Walton's 'art categories' view (1964) for functional objects. Thus, following this view, we can perceive the relationship between a particular form and the function for which the object has been designed. For example, we can perceive that the form of a lamp is appropriate for the kind of thing it is if it seems to be able to give light. That means that form is eloquent with respect to the function that it serves. And the lamp, let's say, seems to be apt or "looks fit" for its purpose.

But, then we can pose the following question: how can function shape our aesthetic appreciation of form? Following some authors (Externalist), function can do this in an indirect manner, following others (Internalist), function shape our perception of form in a direct manner. Among the former, we can locate Externalists, such as Paul Guyer (2002), who defend that function can only "negatively" shape the form in which an object can be considered beautiful. That means that, function is peripheral and is not intimately connected to what makes an object beautiful. So, knowing the object's proper function can only enable us to discard those forms that are inappropriate for a given purpose; however, this knowledge cannot by itself determine whether an object of design is to be judged as beautiful. On the other hand, Internalists maintain that function is integral to the object's correct appreciation. Actually, they claim that form and function are the same thing. That means that knowledge about the function of an object affects our aesthetic perception and judgement of it. For Internalists, function plays an active role: it changes the properties we can perceive in the object-its appearance- making us see it beautiful. This is the integral relationship defended for design aesthetic judgements.

Following this approach, functional beauty judgements are based on the perception of the connection between non-aesthetic properties and the function of an object. That is, a theory of the kind "X functions beautifully". We can say that certain features of an object are attractive given a particular function. Then, the object displays its functionality by means of those indicative features. And, consequently, beauty arises from our consideration of the function in itself related to form. ${ }^{10}$ The key point for functional beauty judgements is the way in which function is to be understood. As Parsons \& Carlson explain: "an understanding of function can affect perceptual appearance, but

9 In De Clercq, R. 2013. "Reflections on a Sofa Bed: Functional Beauty and Looking Fit". Journal of Aesthetic Education, vol. 47, num. 2: 35-48. However, what P\&C stress is the need for knowledge about the object's functional fulfillment. That is a stronger condition for design beauty since that knowledge about the design object is much more specific: we must recognize how it is for the object to successfully work as the kind of thing it is.

10 "Recall again the truism that aesthetic pleasure is pleasure taken in the perceptual experience of an object per se. If we do not know what we are saying when we say ' $\mathrm{X}$ is functionally beautiful', perhaps what we are actually describing is pleasure taken, not in X's perceptual appearance per se, but in some gratification of our needs and desires that X's appearance indicates for us". In Carlson, A. and Parsons, G. 2008. Functional Beauty. New York: Oxford University Press. 
only when it includes understanding of how function is carried out, rather than merely what it is". ${ }^{11}$ That means that it is just not enough to identify the function of a particular object, but rather to recognize the role the object is supposed to perform (a knowledge that we can gain, for instance, with the practical use of the object). So, functional knowledge can directly contribute to a positive aesthetic judgement in that way. ${ }^{12}$ After all, what functionalism holds is a relationship between practical and aesthetic value out of which beauty arises naturally.

\section{A Kind of Dependent Beauty for Design}

Taking into consideration this integral binomial model, Jane Forsey has defended a special kind of functional beauty for design: what she calls Dependent Beauty. On Forsey's view, instead of stressing the fact that the object successfully fulfils its function, it is more relevant for design appreciation to stress the way in which the form actually performs it. That means that dependent beauty arises partly from the contingency of the object's form in relation to its function. Accordingly, our aesthetic judgement will be about this indeterminacy of form with regard to an object's functional kind. In other words, it will be about judging a particular formal solution among all the possible ways in which this form can be solved for a proper function. How is this so? According to Forsey, the aesthetic judgement of design objects is to be reflexive upon the object's "teleological style"; that is, it must result from the reflection upon the way in which the object fulfils its purposive function. As a distinct kind of functional beauty, dependent beauty emphasizes the idea that what makes an object of design beautiful is the economy or frugality of the solution regarding form, rather than its functional role. Consequently, when we perceive the proper beauty of design, form should be as simple as possible. And, that, furthermore, is the reason why the object looks fit. For instance, think about "the sexiest chair of the world", the Panton Chair by Verner Panton (figure 1).

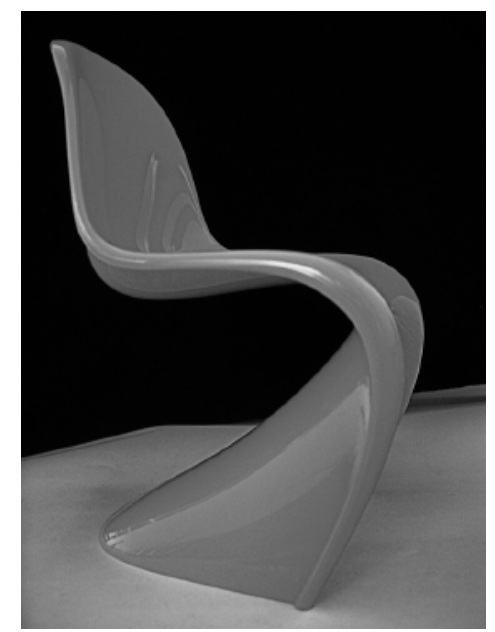

Panton Chair, Verner Panton (1960)

11 Ibid., p.94.

12 Nevertheless, to know how an object functions is not the same as to "attest" that it functions. Knowledge about function helps us to perceive features related to functionality. But we do not have to test the object's functionality in a practical sense. This is another question about what makes a design a good one, but not necessarily an aesthetic question. 
However, Parsons (2016) has criticized this view by arguing that it will be a narrow way of understanding design aesthetics. He claims that, following Forsey's approach, we would only positively appreciate cases of design in which properties of the object are standard for the kind of thing the design object is (that is, those properties that would be standard for the functional category in which the object under appreciation is included). In this sense, we would just consider the features of the object that seem to fit for a particular function; that is, the ones that apparently would be more appropriate for its functional kind. However, this only leaves room for the aesthetic properties related to the object's 'looking fit' aspect, since what we perceive is the object's formal 'correctness'. But what about those features that seem to be unfit or variable for a proper function? As Parsons explains, there are cases in which properties are perceived as contra-standard or variable for a certain functional category. That means that features of the object seem to look unfit or inapt for the functional kind to which the object supposedly belongs. In those cases of (formal) unfitness we can perceive a different aesthetic property called "looking unfit". ${ }^{13}$

The point then turns to what is to be an "appropriate" formal solution for a design object. On Forsey's less restrictive view, since form is contingent regarding an object's proper function, there is no constraint upon which properties can be considered as the focus of aesthetic attention. In fact, after her view, all features might look fit for a function as long as the object works. As described before, beautiful design objects will be those that stand out as simple or sophisticated formal solutions. Following a different line, Parsons focused upon cases where, despite the object being apparently "inappropriate" for its function, the object's form is actually functionally appropriate. Thus, judgments about an object's functionality can be more trustful when we are to judge design from an aesthetic point of view. This knowledge determines a higher range of qualities that can count as standard, contra-standard and variable to a given functional category and can help us locate the object's form in the right functional framework. However the differences between Parsons and Forsey, both share the idea that an object's function determines the aesthetic properties the object possesses qua design and, furthermore, that whatever form that seems to properly satisfy a purposive function, will result in the object's possession of the aesthetic property of looking fit/ unfit. That means, eventually, that this property is necessary for design beauty. ${ }^{14}$

To sum up, why does this binomial model (form-function) fits well with design? Because, insofar as it takes into account design's essential practical function, it can appropriately ground the aesthetic judgement of design objects qua design and, furthermore, it can explain the normative character of the aesthetics judgements of design objects by attending to the kind of thing design is. At least, the approach does not contemplate the aesthetic appreciation of design as a matter of (formal) beauty alone. Instead, it is a question about how form conveys something else, such as a function (design) or a meaning (in the case of art) and how it does this by fitting within

13 P\&C mention the Schreckgost's chair as a case of unfitness, though is not a different perception from the first time the Panton Chair was made public.

14 As Rafael De Clercq remarks, "looking fit" entails a strong condition (for design) since an object has to appear to have certain features which are indicate of functionality. But this is problematic once he shows that perceptual properties are not reliable 'indicatives' of functionality. Against the necessity of looking fit for Functional Beauty see De Clercq, R. 2013. "Reflections on a Sofa Bed: Functional Beauty and Looking Fit". Journal of Aesthetic Education, vol. 47, num. 2: 35-48. 
a particular kind of artefact. Ultimately, working well means it has to be that way. ${ }^{15}$

\section{Main Problems for Any Functional Beauty Account}

As far as it goes, Functional Beauty accounts seem to catch what is specific for design beauty judgements. However, we believe this model presents some problems when compared to our actual design appreciative practice:

\section{i) Practical function is not essential to design beauty}

The first main problem can be stated as follows: How shall we deal with cases that are apparently beautiful -attractive, appealing, etc.- as design but that are clearly nonfunctional or that fail to accomplish its proper function as presumably practical? Can in that case a design object be functionally beautiful? Let's look at Katerina Kamprani's Uncomfortable Chair 3. One from The Uncomfortable Collection (2012) that is composed by deliberately inconvenient everyday objects such as glasses, forks, umbrellas, doors or pots. This uncomfortable chair made in rough textured plastic has been designed with a concaved form seat so that it seems to be impossible to sit down without falling into the ground. In that sense, what this chair tries to attempt to is against the 'proper' function of a chair conventionally conceived as a (comfortable) place to sit down. Hence, there is no practical function for this chair. What would the functionalist say about this design object? Following the form/function binomial model, this object, considered as a chair, couldn't be, properly speaking, judged as beautiful. At most they may say that this chair might be a beautiful case considered as a different kind of thing -an artwork for instance- but not qua design. The reason behind this claim is that it is not a functional object in a practical sense. On one hand, some of its most relevant chair's features are contra-standard and variable for a chair's functional kind so accordingly the chair does not appear to be functional. On the other, there is no way we can sit down in it without risking our back. So, on both Parsons's and Forsey's criteria, this case would have to be judged as aesthetically unpleasant.

However, there is no problem on claiming that this chair might be a beautiful design object -and maybe its beauty is not unconnected to its 'inaptness'- while, at the same time, recognizing the role that knowledge about function plays in our design aesthetic judgements -that it integrally affects our perception of the object. This knowledge concerning the functionality of the object is related to our perception the form of the chair to the extent that the chair does not only apparently seem to be inapt for its conventional or practical function but also, we know that it cannot work for that task. Since it does not practically function as a chair, it cannot be a case of the object's merely looking unfit. It is a non-functional design object that nonetheless can be beautiful as design by being quite "dysfunctional". Although this claim disputes with the idea that design objects are only the ones that have practical functions. Beautifully said, the point is that functional accounts are not consistent with design cases in which aesthetic judgments are not entirely supported by the object's practical or functional success.

Yet, we can go further with another chair case. One in which we can sit down but which is not to sit down either. Consider This is a Lamp by Tobias Wong. In this case, Wong transforms the iconic Bubble Club chair -originally designed by Phillippe Starck-

15 Let's keep in mind that this integral model is not exclusive of functional beauty accounts. A similar form-content model also can work for art as Peter Lamarque suggests for poetry (2018). 
into a lamp. What he aims is to question the notion of authorship by denying the proper function of the original design. Actually, his work can be understood as being guided by an intention closer to the kind of intention issuing in conceptual art. Here the point is that we have no problem in perceiving the aesthetic property of looking fit for the object. Insofar as it is an instance of the Bubble Club model it is both functional as a chair and as a lamp -it serves the function of sitting down and it shines. However, as the kind of thing it is -a Wong's lamp-its proper function is a different -and more complex- one: that is, challenging authorship in design by turning a recognizable chair into a lamp. Then, the problem arises from the fact that if This is a Lamp somehow questions the notion of function in design and, what is more, it does so without being a dysfunctional object. One can sit down on it. Moreover, it gives light too (though function is not technically, but theoretically, denied). So, This is Lamp functions at the same time - and is appreciable-as a chair, as lamp and as an idea. In fact, it is difficult to come with a single functional beauty judgement resulting from the consideration of the object's form and its intended function. Following the Functional Beauty Account, this judgement is to be based on some correspondence between certain perceptual features and a particular function, how shall we judge whether this object is it "functionally appropriate" as design in this case? There are some interferences in the judgement of perceptual correspondence. In this sense, complex cases in which the object's functions (not all practical functions) are so intermingled cannot be well accommodated within the model of functional beauty judgements.

Nevertheless, to deny that judgments about the successful functionality of an object are necessary for a design object to be properly appreciated as beautiful does not involve giving up on the idea that essential or original functions are relevant to design beauty. Despite Forsey's and Parsons's commitment with the idea that practical function provides the key aspect that distinguishes design objects from other kinds of artifacts -like artworks or craft objects-, the aforementioned cases problematize the way in which they conceive the impact of judgements about functionality upon aesthetic judgements of design objects. Albeit function must be certainly taken into account when aesthetically appreciating design objects, it does not determine by itself alone whether a particular design object deserves aesthetic praise or dismissal.

As we have seen, deciding which is the proper function of an object leads to the problem of indeterminacy for functional beauty accounts. Briefly, this problem challenges the idea that an object's proper function can be fully determined. Thus, there are some counter-examples coming from the consideration of some multifunctional artefacts mostly from architecture- that introduce a serious problem to the Functional Accounts. This problem revolves on the idea that design objects are identified by a single functional purpose. ${ }^{16}$ This is an open critical line from where this integral relationship between form and function can also be discussed. For instance, it introduces that not only proper function is responsible of design beauty but accidental functions too.

Taking into consideration what the aforementioned cases show, I want to underlie that even when the Functional Beauty Accounts cannot welcome our first case because

16 For a cogent approach to interlaced functions in multifunctional artifacts where 'shortal' concepts relative to essential or original functions are defended as determinant to aesthetic appreciation see De Clercq, R. 2013. "Reflections on a Sofa Bed: Functional Beauty and Looking Fit". Journal of Aesthetic Education, vol. 47, num. 2: $35-48$. 
it is not functional as design, we could argue for a positive aesthetic appreciation of this object as design. The same concern is identified in the second case. In that case, in spite of being a functional design object, it seems that what is primarily appreciable is the idea with which the designer has produced the object. Actually, our judgement about its beauty is to be attached to the reflection it triggers, rather than on its successfully giving light or on being so comfortable. On my view, in those cases the binomial model form-function is problematic for our design aesthetic judgements. In fact, if we stick to the Functional Beauty Account, the range of design objects that could be welcome as aesthetically good design would be very narrow, partly because the scope of relevant features is limited to functional ones. But, as the examples analysed above show, we need a broader understanding of design aesthetic appreciation if we are to explain our positive aesthetic evaluation of design objects whose aesthetic value cannot be merely cashed out in terms of form/function

\section{ii) Expressive properties are relevant to design aesthetic judgements}

On the other hand, there is another idea that shapes the functional view that I find especially problematic. This view takes as obvious the fact that people mainly find pleasurable objects that look "highly fitting" for its function. And, furthermore, they consider this pleasure is an aesthetic pleasure. However, two things could be said in relation to this claim. First, it seems we need an argument that shows that a judgement based on the perceived functional fittingness is an aesthetic judgement. And, second, we need an argument to show that only judgments concerning the functionality of an object are to be relevant for the aesthetic appreciation of design objects.

As we have seen, both $P \& C$ and Forsey tend to collapse judgments of functionality with judgments of beauty. Nevertheless, as we have tried to show, taking into consideration that the object's functional success does not fully govern our design aesthetic judgments, there is room to argue for a broader notion of design beauty. Second, there is no reason why this pleasure has to be understood exclusively in terms of fittingness. There are other kind of properties -which are not strictly speaking based on functional considerations, such as expressive properties- that may be part of the aesthetic appreciation of design objects. The Functional Beauty Account is wrong in thinking that aesthetic judgements which are partly based on functional considerations are to be exclusively based on those kinds of considerations. ${ }^{17}$ Let us call this the problem of exclusivity of functional beauty accounts.

This problem arises from the idea that only functional considerations are legitimate to our design aesthetic judgments and, consequently, that any other consideration beyond the satisfaction of a function by a particular form only blurs what is really important to our aesthetic appreciation of design objects. So, this narrow appreciative focus excludes all expressive design properties that do not seem to directly bear in favor of the functional success of the object. But if we think, for example, on the variety of ornaments that can be appreciated in everyday objects (in forks, chairs, cars, buildings...) and that cannot be properly perceived in relation to the satisfaction of a

17 At the end, this exclusive character of functional accounts is based upon the guarantee that some apparent features of the object are indicative of functionality (that there is a kind of translation between functional features into formal features). This way relevant aesthetic properties will always reveal the object's functional condition. Although this idea has been recently challenged in De Clercq, R. 2013. "Reflections on a Sofa Bed: Functional Beauty and Looking Fit". Journal of Aesthetic Education, vol. 47, num. 2: 35-48. 
particular 'functional' form, we soon realize that the Functional Account falls sort of giving these aspects their due role in our aesthetic appreciation. Why should not they be considered as part of the aesthetic pleasure provided by the object? How can an object work poorly for that matter? In this regard, it seems unfair to disregard properties that do not appear to contribute to the functional fulfilment of an object and to deprive them of their role in our aesthetic appreciation of design beauty. ${ }^{18}$

This idea can be nicely supported by Hella Jongerious designs. Among her huge collection of design objects, we find Nymphenburg Sketches (2004), a series of unexpected Animal Bowls. They are common bowls that contains sculpted animals from the Nymphenburg's Animal Archive and which are narratively decorated with original patterns from the company's cups and saucers. The peculiarity of this design is that the sculpted animals have a huge size and they almost occupy the entirely useful surface of the bowl. That is seemingly a difficult design object to be integrated in our everyday crockery. But, nevertheless, these bowls' expressive properties seem to make them specially aesthetically appreciable. As Jongerious declares about her designs, here what we have is an usable object that seem to tell their own story. She adds further that this is possible because useful objects are highly saturated with references so it is possible to communicate new stories about them -and through them- by making explicit reference to their specific moments of production in history and their contexts of use. In this sense, functionality isn't really that important because you could think of a different function for a bowl or a cup. ${ }^{19}$ So, following these suggestions, we would endorse a view of design aesthetic appreciation where there is room for expressive design attempts beyond design functional interests.

Therefore, under our proposal, if we appreciate the object of design qua design, those expressive properties can be considered aesthetic properties while still playing their expressive role. That is, they do not necessarily feature in our aesthetic appreciation of design in a detrimental way. ${ }^{20}$ The fact that they are not explained in functional terms does not mean they are not central aspects of the appreciation of design qua design. After all, it seems that the pleasure of beauty in design does not always come with the fact of perceiving the aesthetic property of "looking fit". ${ }^{21}$ That means that our aesthetic judgement still maintains a certain autonomy with regard to function (that the link is not so intimate in all cases).

At the same time, this question connects with a peculiar trait that I think to be crucial for modernist design approaches. As a rule, functionalist approaches maximize simplicity and minimalism as the most relevant design aesthetic features. ${ }^{22}$ And they

18 As Stephen Davies claims: "the aesthetic interest of a given kind of item depends mainly on its variable properties, especially as regards its representational content and expressive character". In Davies, S. 2010. "Functional Beauty Examined". Canadian Journal of Philosophy, vol. 40, num. 2: 315-332.

19 (Italics are mine). In Coles, A. 2007. "Louise Schouwenberg: A conversation with Hella Jongerious that might have taken place (2003)" in DesignArt, London: Whitechapel Gallery and The MIT Press, pp. 89.

20 Towards the idea of design as an art practice that can be 'expressive' see Shiner, L. 2015. "Art Scents: Perfume, Design and Olfactory Art”. British Journal of Aesthetics, vol. 55, num. 3: 375-392.

21 However, this does not mean that fitness is one thing and somehow beauty an additional virtue of the useful object.

22 As if "designers are bound to realize that is their task to explain the nature of the object by its appearance, that is, to create a pattern of visual forces correspondent to the physical pattern which is characteristic for the functioning of the object". In Arnheim, R. 1964. "From Function to Expression". Journal of Aesthetics and Art Criticism, vol. 23, num. 1: 29-41. 
succeed in so doing by downplaying the importance of other traditional aesthetic design values, such as artistic elements and the traces of the designer's self-expression (think for example in the Arts\&Crafts movement). Thus, to adopt simplicity as the major value of design practice disables design to convey certain valuable content as, for example, the one related to expression. In fact, if we consider again Little Sun Diamond, we realize that its form and its proper appreciation requires more than mere functional consideration. Why to complicate its form by making it metaphorical if not for saying something more than "the whole point is to give light"? ${ }^{23}$ What should we say about these expressive properties and their role in the aesthetic appreciation of design objects? The main idea is that to take function as the only reason for design beauty ignores the possibility of accounting for certain expressive properties that surely lie beyond considerations about an object's proper function. As a consequence, all functional approaches relegate design to a mute condition. That is so because -as functional objects- design objects do not need to express more than their 'practical' function (or anything that does not contribute to it), which in turn eventually means that they cannot be beautiful qua design for other reasons than functional ones.

My point is that we can go further than the Functional Beauty account allows once we see the limitations of this model and the objection against the exclusivity of its cognitive commitment with respect to functional beauty. As I have tried to show, the model is too narrow because for it, eventually, the correctness of functional beauty judgements rests upon the object's functionality as a necessary and sufficient condition. However, as I have tried to show with the aforementioned cases, there is also a relevant content to our aesthetic judgement beyond the practical function of the object of design: a content which can be characterized in terms of its expressive, historical and social properties.

\section{Conclusions}

To summarize, the functional view focuses upon the understanding of how function can affect our perception of an object's form and, thus, can determine its aesthetic value. For the aesthetic theory of design, the idea that form's appreciation can be determined by functional considerations is welcome. However, I find problematic and disputable that the aesthetic judgement of design becomes exhausted in the appreciation of form as fit or unfit.

For that matter, the proper aesthetic framework we need for design appreciation goes beyond its functional dimension. Hence, I argue that design beauty is not only grounded upon perceptual properties of the object, that is, on a kind of formalism supported by function, but also upon a broader scope of appreciative properties for design -such as expressive properties. That means that the aesthetic dimension of design is so rich that it overflows the functional view.

\section{References}

Arnheim, R. 1964. "From Function to Expression". Journal of Aesthetics and Art Criticism, vol. 23, num. 1: 29-41.

Carlson, A. and Parsons, G. 2008. Functional Beauty. New York: Oxford University Press.

23 That is what I understood from Olafur's declarations as: light is power and the power (of changing the world) is in your hand. So, the form of a "rough diamond" metaphorically embodies this idea. 
Coles, A. 2007. DesignArt. London: Whitechapel Gallery and The MIT Press.

Davies, S. 2010. "Functional Beauty Examined". Canadian Journal of Philosophy, vol. 40, num. 2: 315-332.

De Clercq, R. 2013. "Reflections on a Sofa Bed: Functional Beauty and Looking Fit". Journal of Aesthetic Education, vol. 47, num. 2: 35-48.

Folkmann, M.N. 2013. The Aesthetics of Imagination in Design. Cambridge: The MIT Press.

Forsey, J. 2013. The Aesthetics of Design. Oxford: Oxford University Press.

Parsons, G. 2016. The Philosophy of Design. Cambridge: Polity Press.

Pye, D. 1978. The Nature and Aesthetics of Design. New York: Van Nostrand Reinhold.

Riis Ebbesen, T. 2017. "Little Sun: An Indicative Framework for the Analysis of Art and Design Objects". Design Issues, vol. 33, num. 1: 48-60.

Sauchelli, A. 2013. "Functional Beauty, Perception, and Aesthetic Judgements". British Journal of Aesthetics, vol. 53, num. 1: 41-53.

Scruton, R. 1980. The Aesthetics of Architecture. Princeton, NJ: Princeton University Press.

Shiner, L. 2015. "Art Scents: Perfume, Design and Olfactory Art". British Journal of Aesthetics, vol. 55, num. 3: 375-392.

Stecker, R. 2019. Intersections of Value: Art, Nature, and the Everyday. Oxford: Oxford University Press. 


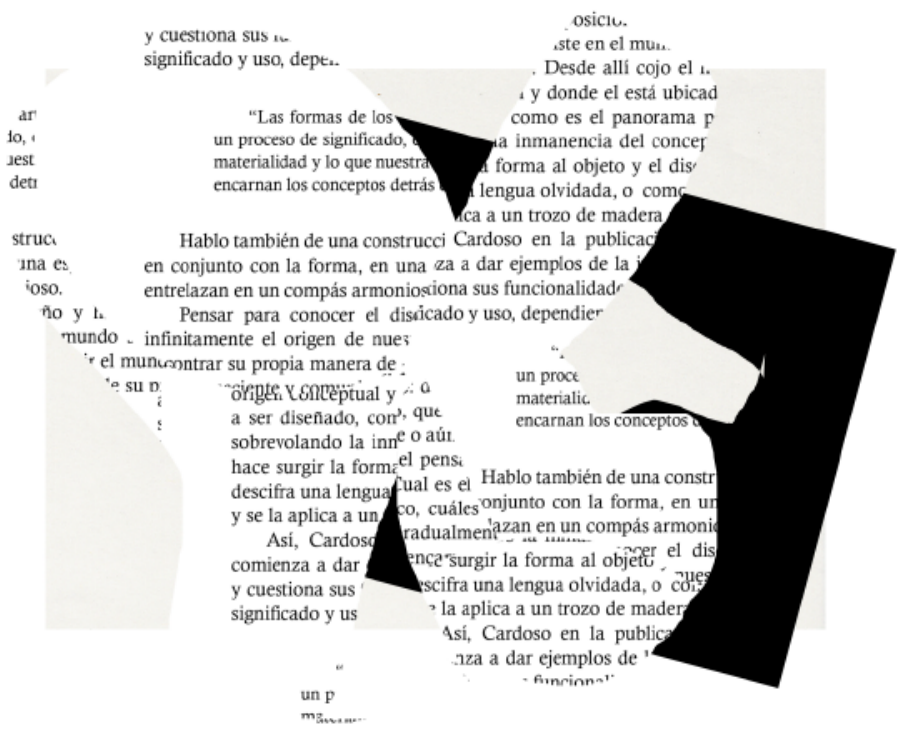

"Lo impreso exige una humildad de espíritu por cuya falta muchas de las bellas artes se tambalean ahora en experimentos de autoconciencia y sensiblería. No hay nada simple ni aburrido en lograr una página transparente. La ostentación vulgar es el doble de fácil que la disciplina".

Beatrice Warde, The Crystal Goblet, or why printings should be invisible (1930)

"El diseño que es objetivo, comprometido con el bien común, bien compuesto y delicado, constituye la base del comportamiento democrático".

Josef Müller-Brockmann, Grid and Design Philosophy (1981) 

EDITA

\section{SEyTA.}

SOCIEDAD ESPAÑLAA
DE ESTETICA Y TEORIA DE LAS ARTES

CON LA COLABORACIÓN DE

\begin{tabular}{|c|c|c|}
\hline 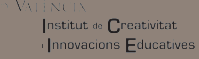 & $\begin{array}{l}\text { VNIVIRSIIN } \\
\text { II) VIIINCL Departament de Filosofia }\end{array}$ & 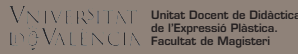 \\
\hline $\begin{array}{l}\text { ESTETICA } \\
\text { FLOSOFIA }\end{array}$ & 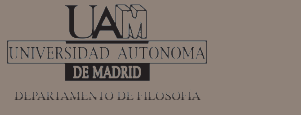 & $\begin{array}{l}\text { UAB } \\
\begin{array}{l}\text { Universitat Autònoma } \\
\text { de Barcelona }\end{array}\end{array}$ \\
\hline
\end{tabular}

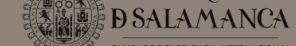

https://ojs.uv.es/index.php/LAOCOONTE/index 